\title{
O lúdico no ensino de genética: proposição e aplicação de jogo didático como estratégia para o ensino da $1^{\text {a }}$ lei de Mendel
}

\section{The ludic in genetics teaching: proposal and application of a game as a didactical strategy for the learning of the Mendel's $1^{\text {st }}$ law}

\author{
Valena da Silva Teles (valenateles.bio@gmail.com) \\ Universidade Federal Rural da Amazônia (UFRA) \\ Jailson Silveira de Souza (nosliaj16@ hotmail.com) \\ Universidade Federal Rural da Amazônia (UFRA) \\ Elaine Silva Dias (elaine.dias@ufra.edu.br) \\ Universidade Federal Rural da Amazônia (UFRA)
}

Resumo: Os jogos didáticos auxiliam no processo ensino-aprendizagem por integrarem $\mathrm{o}$ aprender e o brincar. $\mathrm{O}$ objetivo deste estudo foi o de desenvolver um jogo didático e avaliá-lo como instrumento facilitador da aprendizagem do conteúdo de genética referente à $1^{\text {a }}$ Lei de Mendel. $\mathrm{O}$ jogo produzido foi o do tipo tabuleiro, nomeado "Na Trilha com Mendel", e este foi aplicado em duas turmas do $2^{\circ}$ ano do ensino médio. Questionários foram utilizados para obter informações sobre a contribuição do jogo para a aprendizagem dos alunos e as percepções de ambos, alunos e professores. O jogo resultou em uma melhora na taxa de respostas corretas, com um aumento médio de $11 \%$ na comparação das respostas antes e depois o jogo. Além disso, a partir dos questionários de percepção, observamos uma melhora na relação aluno-aluno. O estudo também fornece informações sobre as dificuldades em aprender e ensinar a $1^{\text {a }}$ Lei de Mendel. O jogo, aqui proposto, contribui para o ensino do conteúdo específico, constituindo-se como um instrumento alternativo para o processo de ensinoaprendizagem de genética, outrossim, a ferramenta proporciona uma melhor interação entre os sujeitos da sala de aula.

Palavras-chave: Ludicidade; Jogos educacionais; Mendelismo.

Abstract: Didactics games help to teach by integrating learning with fun. This study aimed thus to develop a didactic game and evaluate it as a facilitating instrument for learning Mendel's $1^{\text {st }}$ Law in genetic classes. A board game was produced, named " $\mathrm{Na}$ Trilha com Mendel", which was applied in two second year high school classrooms. Questionnaires were used to gather information about the game contribution to the student learning and the perceptions of both students and teachers. The game led to an improvement in the correct answers rate, with an increase of $11 \%$ on average, when comparing the answers before and after the game. In addition, from the perception questionnaires, we observed a betterment in the student-student relationship. The study also provides information about the difficulties in learning and teaching Mendel's $1^{\text {st }}$ Law. The game, proposed herein, contributes to the teaching of the specific content, constituting itself as an alternative instrument for the teaching-learning process in 
genetics; moreover, the tool provides a better interaction among the individuals in the classroom.

Keywords: Playfulness; Educational games; Mendelism.

\section{INTRODUÇÃO}

Nos últimos anos, estudos que investigam estratégias metodológicas no ensinoaprendizagem de genética têm ocupado um espaço relevante na literatura especializada (RAMALHO et al., 2006; GUIMARÃES et al., 2008; PAES; PARESQUE, 2009; PAIM; SENE; MOTA, 2017; BRÃO; PEREIRA, 2015; SANTIAGO; CARVALHO, 2019). Esses trabalhos, em grande parte, investigam as dificuldades encontradas no ensino dessa disciplina, que ocorrem, sobretudo, devido à sua extensa terminologia e ao seu alto nível de abstração. Diante do grande número de conceitos, os alunos optam por decorar os termos ao invés de compreendê-los e relacioná-los entre si e com a vida cotidiana (TEMP, 2011). Uma vez feita a escolha pelo método de memorização, os alunos se distanciam de uma aprendizagem que lhes possibilite a aquisição e o domínio de conhecimentos necessários para a compreensão do mundo, dos limites e das possibilidades da ciência e do papel do homem na sociedade na qual está inserido.

Não obstante às dificuldades a serem superadas no ensino de genética, encontramos em sala de aula o predomínio de aulas tradicionais que têm o professor sempre como protagonista (CAMARGO; DAROS, 2018). Esse modelo já ultrapassado de transmissão e recepção de conteúdo gera desinteresse e, consequentemente, deficit na aprendizagem (KRASILCHIK, 2008). Particularmente no contexto da biologia, Krasilchik pontua que a escolha da metodologia pode tornar essa disciplina uma das mais relevantes ou uma das mais insignificantes, dependendo do conteúdo dessa área trabalhado e de como este é transferido aos alunos. O uso de práticas metodológicas diversificadas, que rompa com o modelo atual de transmissão e recepção de conhecimento no ensino de biologia, seria uma alternativa para a promoção de um ensino mais dinâmico e motivador (ARAUJO; SANTOS, 2014). Para Morán (2015), metodologias ativas visam inverter o ator principal, nelas o aluno passa a ser o protagonista e se torna ativo, crítico e reflexivo em seu processo de aprendizagem. E quando direcionado ao ensino de genética, Martinez e colaboradores (2008, p. 24) destacam que "métodos inovadores de ensino que envolvam arte, modelos e jogos, mostram-se promissores para serem aplicados no ensino de genética". De acordo com 
os autores, tais atividades, quando aplicadas de forma lúdica, complementam o conteúdo teórico e estabelecem uma boa relação entre aluno e professor e, como resultado, tem-se o aumento do aprendizado.

Por definição, conceitua-se que jogos didáticos são aqueles produzidos com a finalidade de auxiliar no processo de ensino-aprendizagem. Os jogos vão além de somente ensinar de forma divertida e de "sem que o aluno se dê conta", na verdade, eles desenvolvem diversos aspectos cognitivos como a imaginação e o raciocínio (FORTUNA, 2000; MIRANDA, 2001). Nesse sentido, a utilização dos jogos, relacionados ao ensino de genética, poderia despertar a atenção dos alunos, facilitando a aprendizagem desse conteúdo de forma divertida.

Nesta pesquisa, apresentamos uma proposta de jogo didático sobre o conteúdo de genética referente à $1^{\mathrm{a}}$ Lei de Mendel e os resultados de sua aplicação em turmas de duas escolas da rede estadual de ensino do município de Igarapé-Açu, no estado do Pará. De forma inédita, quando comparamos o jogo por nós proposto com outros jogos de natureza similar, fornecemos aos professores uma ferramenta agregada que provê informações avaliativas de aprendizagem, facilitando, assim, a identificação e, consequentemente, a resolução de pontos do conteúdo que, mormente, os alunos apresentam dificuldade.

\section{USO DE JOGOS NO ENSINO DE GENÉTICA}

A genética é responsável pelo estudo do material genético (o DNA) e de seus padrões de herança. Ela apresenta grande impacto na sociedade, sobretudo, por constantemente estar relacionada às inovações científicas na área da saúde e da agricultura (SNUSTAD; SIMMONS, 2013). A compreensão dessa ciência contribui não apenas para entender os mecanismos de transmissão hereditária como também para desenvolver um senso crítico diante dessas inovações científicas.

Não obstante à sua importância, o ensino dessa disciplina tem diversos obstáculos na aprendizagem devido, sobretudo, à complexidade e ao teor abstrato do conteúdo. As queixas dos alunos concentram-se no grande número de conceitos e na falta de metodologias que promovam um aprendizado acessível e estimulador (ARAUJO; SANTOS, 2014; SANTOS; LIMA, 2014). Além disso, encontramos na literatura uma série de dificuldades quanto ao ensino dessa ciência como a falta de recursos, de ambiente adequado, de livro didático, de carga horária e de interesse dos alunos, além 
da presença de cálculos matemáticos que tornam o processo de aprendizagem mais complexo (SOUSA et al., 2016; ARAÚJO et al., 2018; GOLDBACH et al., 2009; TEMP; SANTOS, 2018; FILHO; ALLE; LEME, 2018). Essas ocorrências evidenciam a necessidade de se buscar estratégias que facilitem e tornem mais efetivo o ensinoaprendizagem dessa disciplina.

O uso de ferramentas lúdicas tem destaque na educação em decorrência de trabalhos que revelam sua importância e sua contribuição no processo de ensinoaprendizagem (SALOMÃO; MARTINI; JORDÃO, 2007; COSTA; PINHO, 2008; COSTA; DUARTE; GAMA, 2019). E, associado a esse universo, os jogos didáticos estão cada vez mais inseridos no ambiente educacional pelo fato de estes associarem prazer ao estudo e auxiliarem na aprendizagem (KISHIMOTO, 1990; RAU, 2013; CORDOVIL; SOUZA; FILHO, 2016).

O estudo de Campos, Bortoloto e Felício (2003) aponta os jogos como ferramenta importante no processo de aprendizagem. De acordo com os autores, os jogos aumentam o interesse e desenvolvem vários níveis de socialização dos alunos, além de ajudarem na construção de novas descobertas e no fortalecimento da personalidade; no que diz respeito ao professor, eles possibilitam conduzir, estimular e avaliar a aprendizagem. Os mesmos autores ainda reforçam que esse instrumento pedagógico pode ser utilizado nas práticas escolares para aproximar alunos do conhecimento científico, levando-os a vivenciar, mesmo que de forma lúdica, problemas reais encontrados na sociedade. E, embora não seja o objetivo da atividade, a competição promovida por alguns desses jogos desperta o desejo de vencer e ensina o aluno também a lidar com a derrota ou com a vitória, algo comum no cotidiano de todos nós (FIALHO, 2007). Em consonância com esses benefícios, os jogos didáticos tornam-se uma ferramenta para ensinar conceitos de genética por apresentarem aspectos lúdicos e cognitivos e auxiliarem no aprendizado de conteúdos abstratos (VALADARES; RESENDE, 2009; DE CAMPOS JÚNIOR et al., 2009).

Jogos didáticos de diferentes naturezas têm sido criados e aplicados com o objetivo de auxiliar no ensino de genética. No jogo "Dominó Gênico", por exemplo, o dominó tradicional teve sua face substituída por exemplos de genótipos e fenótipos correspondentes (LEITE et al., 2014). Com a utilização da atividade, os professores relataram maior socialização entre alunos na busca pela resposta correta, além de maior entusiasmo e motivação. No trabalho de Valadares e Resende (2009), os autores 
desenvolveram uma atividade denominada "Na trilha do sangue". Explorando o conteúdo de síndromes genéticas, Gomes e colaboradores (2011) propuseram o jogo intitulado "Jogo da memória", em que o nome de uma síndrome teria que ser corretamente associado à descrição das características ou à imagem de humanos sindrômicos. O jogo foi aplicado em estudantes do ensino médio e gerou entre eles maior entusiasmo em aprender e em assimilar o tema e, adicionalmente, aumentou a interação entre aluno-aluno e aluno-professor. O jogo didático "Perfil da genética", por sua vez, foi criado para instigar o aluno na aprendizagem de variados conteúdos da genética, como tipos de herança, relação entre alelos, interação gênica, geneticistas famosos, ferramentas da biotecnologia e etc.; e, para aumentar a motivação dos alunos (SANT'ANNA et al., 2011). Também no formato de tabuleiro, os resultados de um questionário - que avaliou sua aplicação em alunos do $3^{\circ}$ ano do ensino médio mostraram que a maioria dos alunos disse que o jogo contribuiu para o aprendizado de novos conceitos e achou interessante sua utilização nas aulas.

Os diferentes exemplos de jogos didáticos descritos mostram a versatilidade destes em sala de aula e os benefícios que seu uso pode oferecer. Eles mostram-se como ferramentas estratégicas de ensino, uma vez que promovem o aprendizado de maneira mais instigante, aumentam a socialização em sala, a curiosidade e o desejo em obter mais conhecimento.

\section{VISPROCEDIMENTOS METODOLÓGICOS}

A pesquisa configura-se como uma abordagem qualiquantitativa de natureza aplicada. De acordo Gerhardt e Silveira (2009, p.32), a pesquisa qualitativa "não se preocupa com a representatividade numérica, mas, sim, com o aprofundamento da compreensão de um grupo social, de uma organização, etc". Quanto ao caráter quantitativo do trabalho, segundo Gil (2002), o mesmo se caracteriza pela utilização de instrumentos formais e estruturados para a coleta de dados, como os questionários aqui utilizados. A natureza aplicada deriva-se da obtenção de conhecimentos para a aquisição da prática (desenvolvimento do jogo didático para uso em sala) e dirigidos à solução de problemas específicos (dificuldades no ensino da $1^{\mathrm{a}}$ Lei de Mendel). Sobre essa natureza, Nascimento (2016, p. 2) a define da seguinte forma: "a pesquisa aplicada é dedicada à geração de conhecimentos para a solução de problemas específicos, é dirigida à busca da verdade para determinada aplicação prática em situação particular". $\mathrm{O}$ ambiente de pesquisa foi duas escolas da rede estadual de ensino do município de 
Igarapé-Açu, estado do Pará. A pesquisa foi realizada com 55 alunos do $2^{\circ}$ ano do ensino médio, em junho de 2019.

Os estudantes que se voluntariaram para conceder depoimentos tiveram seus nomes mantidos em anonimato, sendo utilizadas, então, neste trabalho, abreviaturas para a identificação de seus nomes. Todos os participantes do estudo, bem como seus responsáveis legais, concordaram em serem voluntários da pesquisa por meio da assinatura do termo de Consentimento Livre e Esclarecido.

\section{Coleta e análise de dados}

Os dados foram obtidos por meio de três estratégias: (1) Questionário aos alunos, para avaliar o conhecimento específico da área da genética (Quadro 1); (2) Notas de campo, para avaliar o funcionamento e o resultado da atividade bem como mensurar a percepção dos alunos em relação a essa atividade; e (3) Questionário ao docente, responsável pela turma, para se ter uma percepção geral da atividade pelo professor e também abrir espaço para críticas e sugestões (Quadro 2).

Como procedimento de análise do questionário dos alunos foram adotadas duas estratégias. Na questão 1, que solicitou que o aluno apontasse em uma lista de termos aqueles relacionados a $1^{\text {a }}$ Lei de Mendel, o desempenho do aluno foi classificado de acordo com o número de termos associados corretamente. Dessa forma, foi classificado como ruim, 1 ou 2 acertos, regular, de 3 ou 4, bom, 5 ou 6, e excelente, 7 acertos, de um total de 10 itens; sendo que 7 itens são corretamente associados ao contexto da genética, e os outros 3, ao de outras áreas da Biologia. Para as demais questões, todas de múltipla escolha de resposta única, foi computado diretamente o acerto ou o erro.

\section{Jogo didático}

O jogo elaborado é do tipo tabuleiro, baseado no tradicional jogo de trilha, composto por dados, peões, e um baralho com 12 cartas de sorte ou azar e um baralho com 45 cartas, sobre conhecimento específico (Figura 1). Estas cartas são divididas em três categorias: (i) conceito, 15 questões que abordam conceitos; (ii) abstrato, 15 que abordam termos de caráter subjetivo; e (iii) complexo, 15 que envolvem a realização de cruzamentos; sendo cada tipo indicado na parte superior da carta. Dentro de cada categoria, tem-se questões de três níveis de dificuldade, fácil, médio e difícil, níveis estes indicados pela coloração das cartas, verde, amarelo e vermelho, respectivamente (Figura 2). O jogo tem um manual de instruções e um gabarito de respostas que 
auxiliam o mediador do jogo na consulta das respostas dos alunos. Também foi elaborada uma Folha de Respostas (Figura 3). As partes gráficas foram feitas com o auxílio do programa Corel Draw.

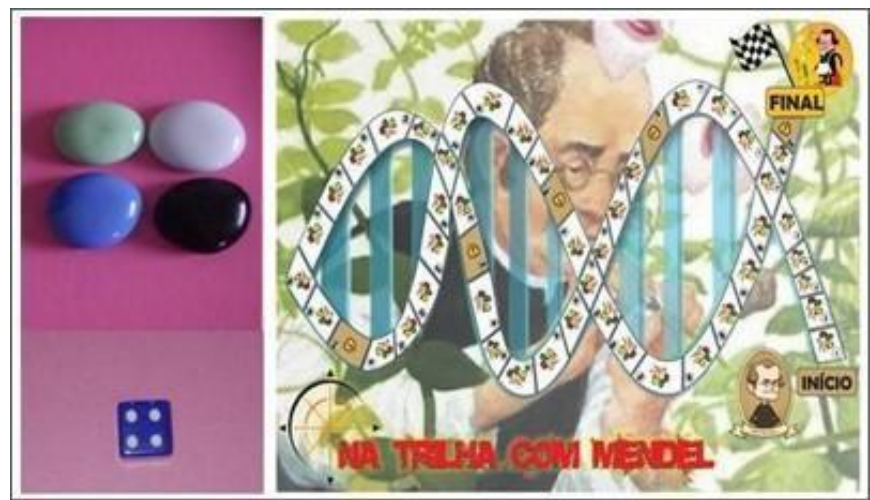

Figura 1 - Componentes do jogo (tabuleiro, peões e dado).

Fonte: Autores (2020).
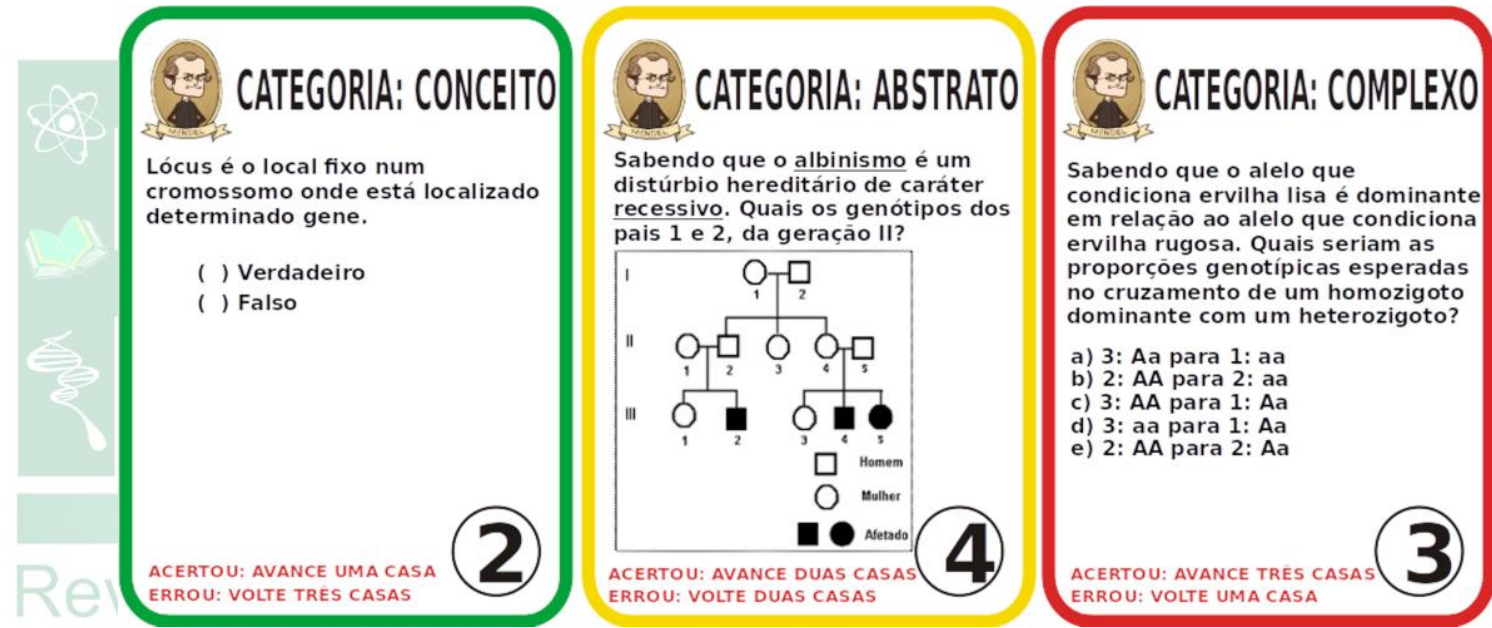

Figura 2 - Exemplos de cartas do jogo. Questões das diferentes categorias, conceito, abstrato e complexo, e dos diferentes níveis fácil, nível médio e nível difícil, da esquerda para a direita, respectivamente.

Fonte: Autores (2020).

Como mencionada, foi elaborada uma Folha de Respostas, que se constitui como um elemento gráfico de "retorno" ao professor (Figura 3). Essa folha contém espaços para que os jogadores marquem a resolução da questão (acerto ou erro, verificado a partir do gabarito fornecido) retirada em cada rodada. Nessa folha são identificados a categoria, o nível e o número da questão. No final do jogo, ela é entregue ao professor responsável pela turma. Esse componente tem como objetivo fornecer um feedback para o professor indicando a(s) categoria(s) e nível(is) das principais dificuldades encontradas pelos alunos. Nesse sentido, a informação gerada pode servir tanto como referência para o professor desenvolver atividades quanto ainda para ajustar suas aulas com o objetivo de solucionar os problemas identificados. 


\begin{tabular}{|c|c|c|c|c|c|c|c|}
\hline \multicolumn{8}{|c|}{ Folha de respostas } \\
\hline \multirow[t]{2}{*}{ Equipe: } & \multicolumn{2}{|c|}{ Categoria / Nível } & \multicolumn{5}{|c|}{ PERGUNTAS } \\
\hline & \multirow{3}{*}{ Conceito } & Fácil & 1 & 2 & 3 & 4 & 5 \\
\hline \multirow[t]{9}{*}{ Nomes: } & & Médio & 1 & 2 & 3 & 4 & 5 \\
\hline & & Dificil & 1 & 2 & 3 & 4 & 5 \\
\hline & \multirow{3}{*}{ Abstrato } & Fácil & 1 & 2 & 3 & 4 & 5 \\
\hline & & Médio & 1 & 2 & 3 & 4 & 5 \\
\hline & & Dificil & 1 & 2 & 3 & 4 & 5 \\
\hline & \multirow{3}{*}{ Complexo } & Fácil & 1 & 2 & 3 & 4 & 5 \\
\hline & & Médio & 1 & 2 & 3 & 4 & 5 \\
\hline & & Dificil & 1 & 2 & 3 & 4 & 5 \\
\hline & \multicolumn{7}{|c|}{ Resposta certa marque: $\bigcirc$} \\
\hline
\end{tabular}

Figura 3 - Folha de respostas a ser preenchida pelo aluno mediador durante o jogo e entregue ao professor no final da atividade.

Fonte: Autores (2020).

\section{RESULTADOS E DISCUSSÃO}

\section{Aplicação do jogo}

O jogo foi aplicado em turmas do $2^{\circ}$ ano do ensino médio, em duas escolas, totalizando 55 alunos participantes (Figura 4). Nas duas escolas, o conteúdo sobre a $1^{\text {a }}$ Lei de Mendel já havia sido ministrado pelas professoras, de modo que o jogo atuou como instrumento de revisão. O tempo de duração foi o de 2 horas-aulas, pequenos ajustes, como tempo limitado para organização dos grupos e das atividades relacionadas, foram necessários e são sugeridos.

De modo geral, os componentes do jogo (tabuleiro, dado, peões, cartas, folha de respostas e folha gabarito) funcionaram dentro do esperado. A atuação do aluno mediador durante o jogo foi importante para a organização das equipes e para a coleta dos resultados. Ressaltamos a importância de uma orientação prévia sobre o preenchimento da Folha de Respostas aos jogadores e aos mediadores do jogo, uma vez que esse elemento tem caráter avaliativo.

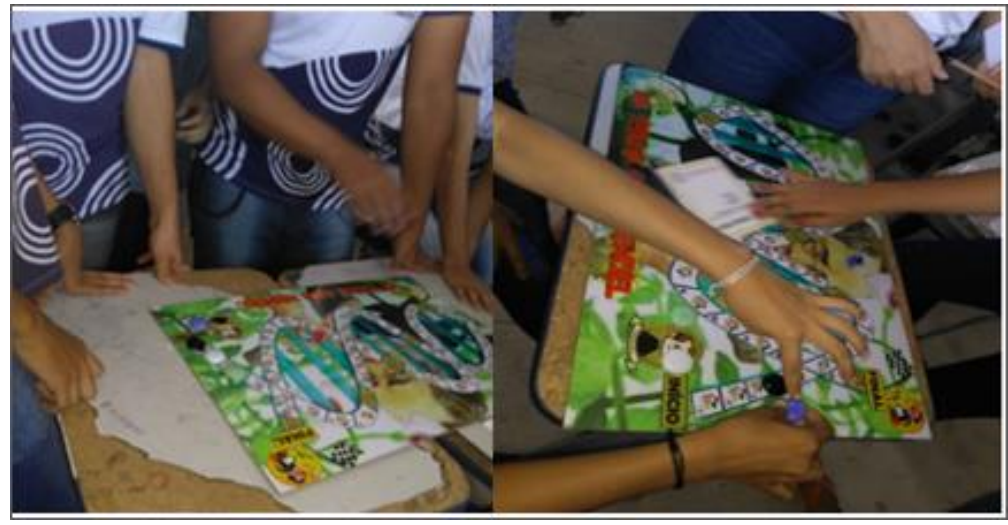

Figura 4 - Tabuleiros utilizados pelos alunos durante o jogo.

Fonte: Autores (2020). 


\section{Resultados gerais}

A contribuição do jogo para a aprendizagem da $1^{\mathrm{a}}$ Lei de Mendel foi avaliada a partir da análise do questionário dos alunos aplicado antes e após a realização da atividade (Quadro 1).

Na Questão 1, antes da aplicação do jogo, nenhum aluno associou corretamente todos os 7 termos da lista de 10 com a $1^{\text {a }}$ Lei de Mendel (Figura 5(A)) e não foram obtidas respostas avaliadas como excelente. No momento pós-jogo, observamos a ausência de respostas classificadas como ruim e a presença de resposta excelente. Assim, após o jogo, o número de respostas classificadas como ruim e regular diminuiu enquanto o número de respostas classificadas com bom ou excelente aumentou. Uma melhora na quantidade de acertos também foi observada para as demais questões (de 2 a 5), destaque para as questões 2 e 4 que aumentaram em $16 \%$ e 18\%, respectivamente, acerca do número de alunos que responderam corretamente (Figura 5(B)).

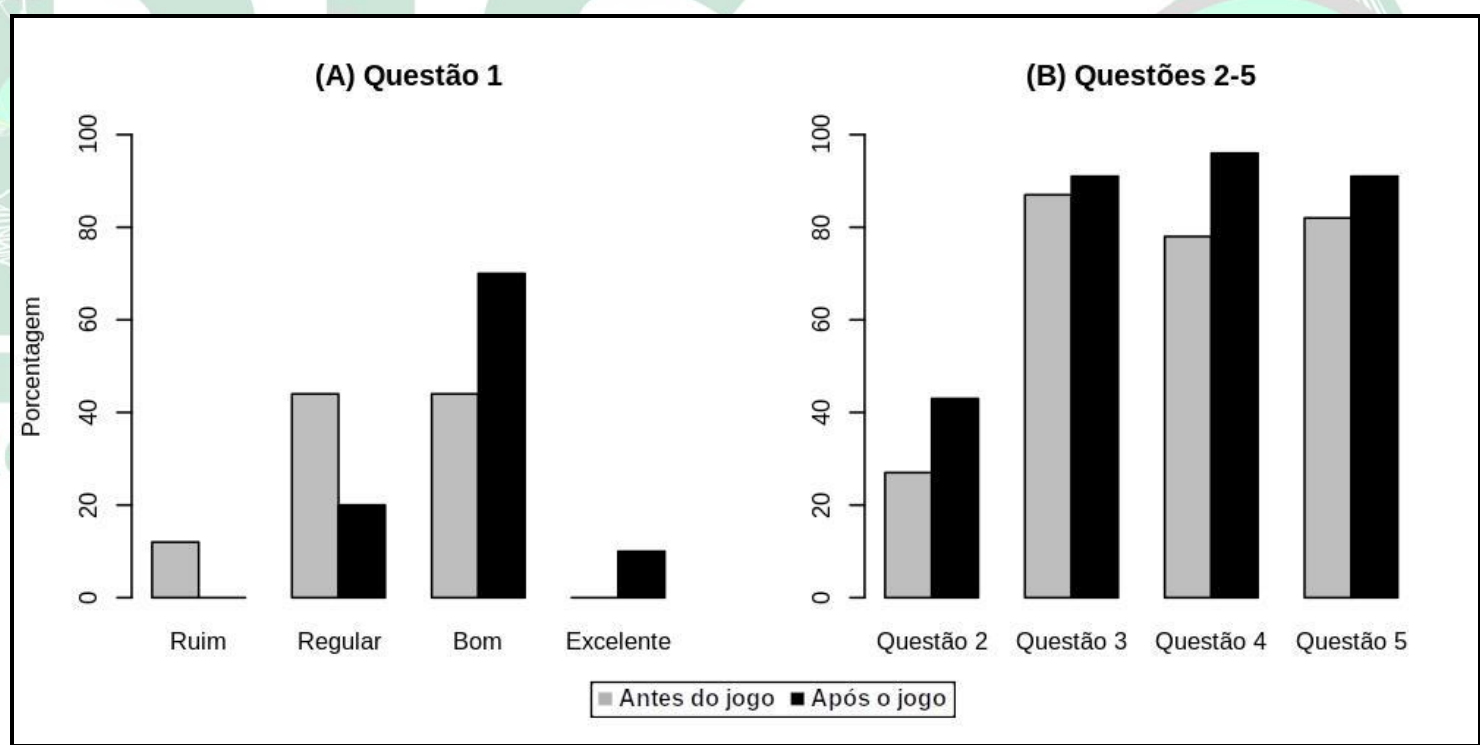

Figura 5 - Desempenho dos alunos (porcentagem de acertos) no questionário antes e após a atividade lúdica.

Fonte: Autores (2020).

A partir dos resultados notamos que o desempenho dos alunos progrediu no contexto pós-jogo, observado pelo aumento de respostas corretas nos questionários após a atividade. Outros trabalhos que aplicaram jogos didáticos e avaliaram a eficiência dos mesmos por meio de questionários obtiveram resultados semelhantes. O jogo " $\mathrm{Na}$ trilha da divisão celular”, de Martins e Braga (2015), também aborda conteúdo da genética, no assunto divisão celular, e o método de avaliação foi similar ao do presente trabalho, um questionário aplicado antes e após do jogo. Os autores relataram um aumento médio de 
16,7\% no desempenho dos alunos das diferentes turmas após a aplicação do jogo realizado pela pesquisa mencionada. No método aqui proposto, após a aplicação do jogo, o número de respostas consideradas positivas, ou seja, boas ou excelentes, na questão 1, aumentou em $26 \%$, e nas demais perguntas, o número de acertos das questões de múltipla escolha saltou de $69 \%$ para $80 \%$, um aumento de $11 \%$. Esses resultados reforçam a contribuição da proposta desenvolvida para o aprendizado do conteúdo específico e reiteram a importância da aplicabilidade de questionários para a promoção de uso de abordagens avaliativas quantitativas.

\section{Resultados específicos}

A partir das Folhas de respostas preenchidas pelas equipes durante a aplicação do jogo, foi possível obter o desempenho dos alunos nas perguntas por categoria e por nível de dificuldade. $\mathrm{Na}$ escola 01 , as equipes responderam um total de 85 perguntas e obtiveram 47 acertos e 38 erros; e na escola 02, o total foi de 90 perguntas, sendo 45 acertos e 45 erros. Questões da categoria conceito obtiveram as maiores porcentagens de acertos, enquanto que as da categoria complexo obtiveram as maiores porcentagens de erros (Figura 6). Quando analisados os acertos e os erros por nível das perguntas, como esperado, os acertos ocorreram, em maior quantidade, nas questões de níveis fácil e médio, e os erros, nas de nível difícil. Combinados, categoria e nível de dificuldade, questões complexas difíceis foram as que mais foram respondidas erroneamente, na escola 02, inclusive, nenhuma questão desse tipo foi respondida corretamente.

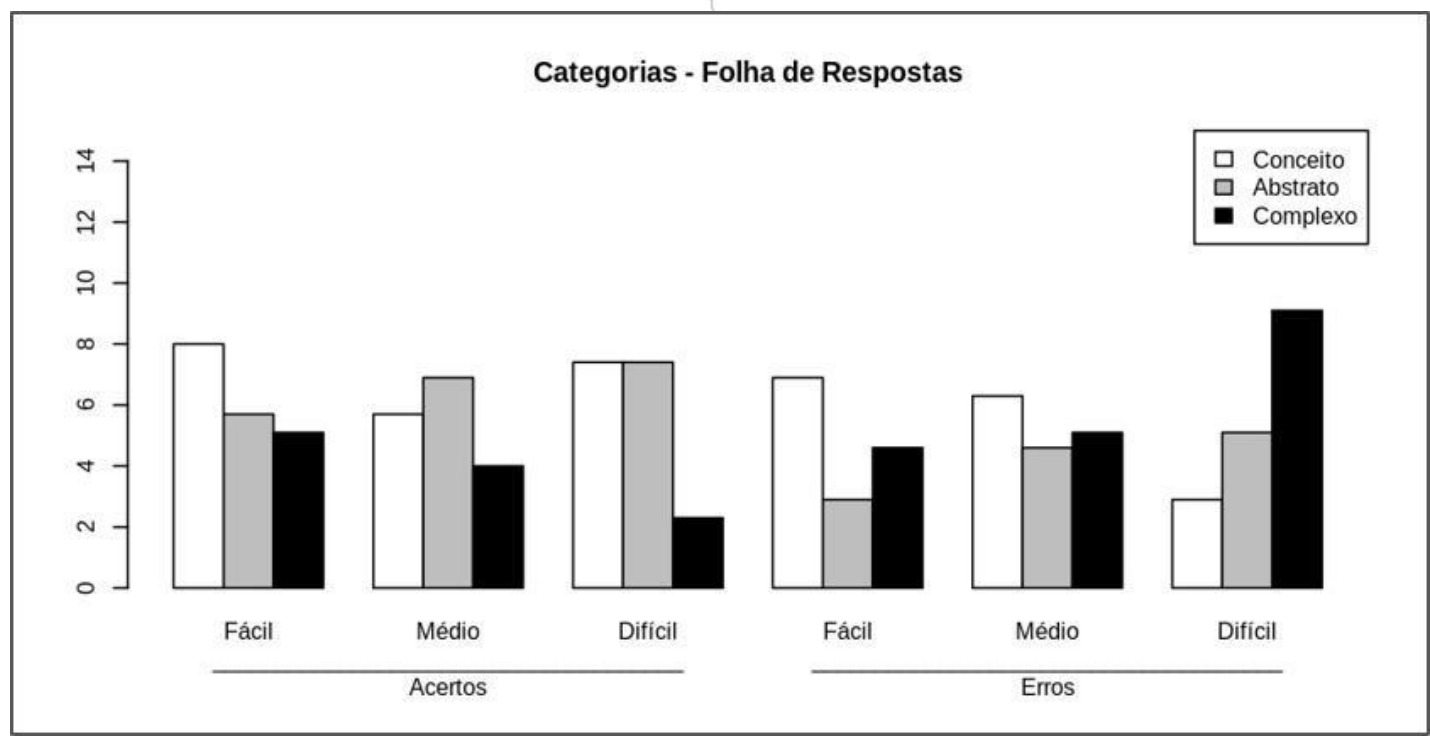

Figura 6 - Porcentagem (\%) de acertos e erros por categoria e por nível.

Fonte: Autores (2020). 
Os resultados observados vão ao encontro do estudo de Sousa et al. (2016) e sugerem que dificuldades no aprendizado de genética podem estar relacionadas ao deficit na formação dos alunos em outras disciplinas, particularmente, em matemática, que é utilizada em cálculos de probabilidade no contexto dos cruzamentos genéticos. Essa mesma dificuldade é encontrada também no ensino superior (DIAS; CARLAN, 2016). Dessa forma, fatores externos ao conteúdo da genética podem influenciar o desempenho dos alunos nessa disciplina, fato que reforça a necessidade de implementação de um ensino multidisciplinar, tão discutido nos dias atuais.

\section{Percepção dos participantes}

A percepção das professoras sobre o jogo foi obtida em um questionário próprio (Quadro 2). As professoras relataram que o jogo "Na Trilha com Mendel” auxiliou na revisão do conteúdo e destacaram, como pontos positivos, o aumento da socialização, interação e participação dos alunos e, como negativo, o longo período de tempo para a realização. Elas ressaltaram, ainda, que o elemento Folha de respostas contribuiu para a identificação das dificuldades dos grupos (Figura 7).

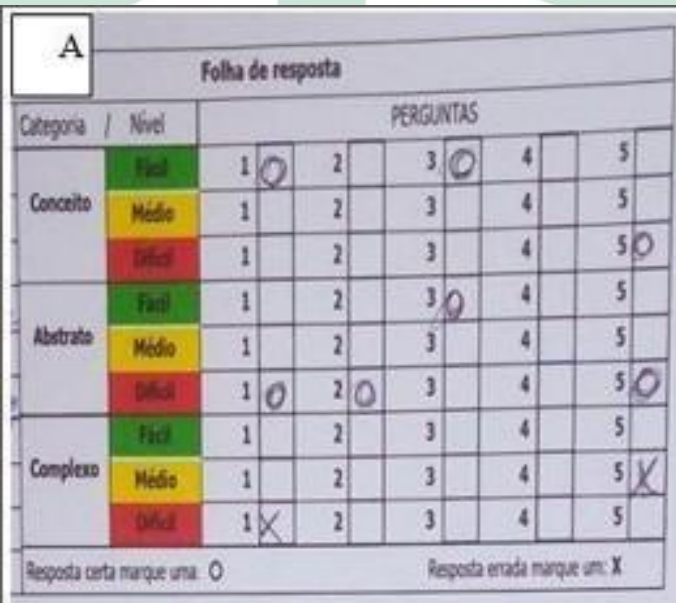

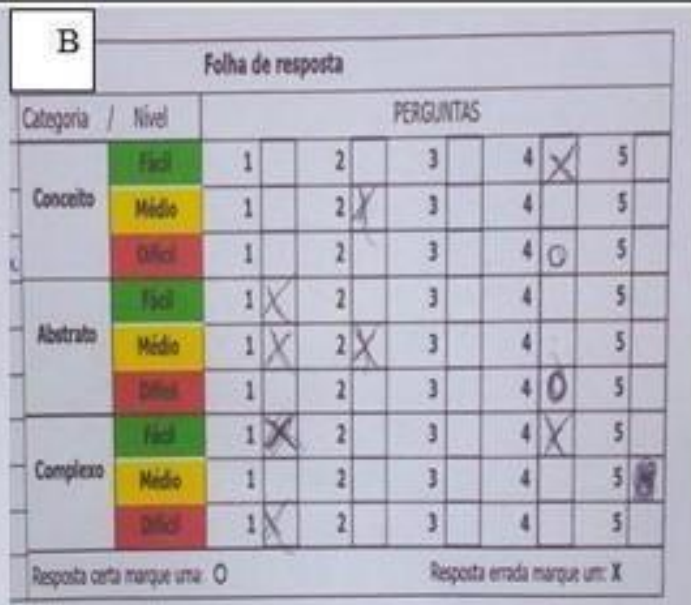

Figura 7 - Exemplo de folhas de respostas obtidas a partir da aplicação do jogo. (A) Exemplo evidencia uma equipe com dificuldade em questões da categoria complexo; (B) Exemplo evidencia uma equipe com dificuldades em todas as categorias e níveis.

Fonte: Autores (2020).

O feedback dado ao docente, a partir da folha de respostas, torna o jogo proposto diferenciado quando comparado com outros similares já existentes. Uma quantidade significativa de estudos tem proposto e utilizado jogos de trilha no contexto da genética (LOVATO et al., 2018; FREIRE, 2009; SANT'ANNA et al., 2011; PAIVA et al., 2008; 
VALADARES; RESENDE, 2009; ARAUJO et al., 2012, entre outros), porém, essas propostas não apresentam um elemento de retorno rápido e claro ao professor.

Por parte dos alunos, o jogo foi bem-aceito nas duas escolas, ainda que alguns deles tenham demonstrado certo receio inicialmente. Essas percepções são reforçadas nos depoimentos fornecidos pelos alunos:

Achei muito importante o projeto, pois algumas pessoas não se interessam pela matéria ou pelo assunto, e esse jogo buscou uma forma diferente para ficar mais interessante. (Al. 1)

Eu gostei muito, porque nos incentivou com o jogo (que foi muito divertido) e relembra tudo o que nós estudamos. (Al. 2)

$O$ jogo foi uma experiência muito boa a qual podemos relembrar assuntos que já estudamos em algo bem dinâmico e divertido. (Al. 3)

$\mathrm{E}$, independente das reações mais tímidas de alguns alunos no contato inicial, o jogo "Na Trilha com Mendel" despertou sensações e comportamentos como: sentimentos de prazer, interação e aproximação. Como declarado nos depoimentos abaixo:

Foi algo novo e muito interessante, pois facilita muito a compreensão de uma maneira divertida, achei ótimo. (Al. 4)

Achei o jogo bastante divertido, nos fez relembrar o assunto e fazer também com que aquelas pessoas que não se interessavam, interagir mais e conhecer mais (foi muito divertido e educativo). (Al. 5)

O jogo foi bem legal, onde tivemos dificuldades em algumas questões, mas foi bom, brincamos e sorrimos entre as equipes. (Al. 6)

Assim, o jogo aplicado proporcionou um ambiente apto para a integração de conhecimento e diversão. Na presença de jogos didáticos, os conteúdos contam com o aporte de interesse e de prazer que os jogos e as brincadeiras proporcionam e aumentam a participação ativa dos alunos e a integração entre eles (SILVA, 2007).

Nossos resultados mostram que a gamificação do conteúdo da $1^{\mathrm{a}}$ Lei de Mendel impulsionou seu processo de aprendizagem. A gamificação consiste em moldar atividades, que não estão diretamente ligadas aos jogos, com o objetivo de alcançar o mesmo grau de entusiasmo e comprometimento dos jogadores durante um jogo lúdico tradicional. Esse processo se dá por meio da inserção de elementos característicos dos jogos, como sistema de feedback, sistema de recompensas, conflito, cooperação, competição, objetivos e regras claras, níveis, tentativa e erro, diversão, interação, interatividade, entre outros (FARDO, 2013). Dentro do universo de gamificar conteúdos 
educativos, os jogos de tabuleiros são os mais amplamente utilizados. Silva e Silva (2018, p. 3) afirmam que "Os jogos de tabuleiros são ótimos para trabalhar a atenção, a concentração, despertar a curiosidade e a imaginação, além de, algumas vezes, possibilitar ao jogador adquirir mais conhecimento sobre determinados assuntos". Dentre os jogos de tabuleiro, o jogo de trilha é o mais utilizado uma vez que possibilita uma associação direcionada do assunto e incita a participação dos alunos (GOLDBACH et al., 2013). Dessa forma, o jogo de tabuleiro "Na Trilha com Mendel”, ao conter os elementos da gamificação, permite que o lúdico se estabeleça, tornando-se, nesse sentido, uma ferramenta que promove socialização, interação, cooperação e competição em um contexto formativo, e que tem o potencial de facilitar a aprendizagem da $1^{\text {a }}$ Lei de Mendel.

\section{CONSIDERAÇÕES FINAIS}

Nossos resultados evidenciam que o jogo elaborado trouxe resultados positivos no que diz respeito à sua contribuição no processo de ensino-aprendizagem do conteúdo da $1^{\mathrm{a}}$ Lei de Mendel nas duas escolas participantes. O aumento médio de $11 \%$ no número de respostas corretas pós-jogo, verificado nas duas escolas, por meio do questionário aplicado, mostra que o jogo auxiliou na aprendizagem dos alunos. A folha de respostas proposta mostrou ser um instrumento eficiente para a identificação das principais dificuldades apresentadas pelos alunos. Além disso, o jogo proposto não só contribuiu para a aprendizagem do conteúdo como também promoveu divertimento e aumentou a interação e a participação dos alunos em sala, aspectos importantes, positivos e característicos quando se faz uso de uma ferramenta lúdica em sala de aula.

Os dados específicos, obtidos a partir da aplicação em salas de aula, permitiramnos ainda inferir que o conteúdo referente aos cruzamentos genéticos se constitui em uma dificuldade importante na aprendizagem da $1^{\text {a }}$ Lei de Mendel, uma vez que as questões sobre o tema foram respondidas de forma errônea mais frequentemente pelos alunos. Por outro lado, de modo geral, as questões conceituais foram respondidas de forma correta mais vezes.

Cabe salientar que dificilmente os jogos didáticos promoverão a superação de todas as dificuldades no aprendizado de genética, e nem se propõe, aqui, substituir aspectos teóricos das aulas, mas a ferramenta pode, sim, tornar-se um elemento auxiliador em sala e, eventualmente, assumir mais espaço na prática docente. Por fim, 
espera-se que o "Na Trilha com Mendel" não apenas se limite ao seu uso em sala, mas também estimule a elaboração de novos trabalhos na busca por melhoria no ensino de genética e de outras disciplinas.

\section{REFERENCIAS}

ARAUJO, K. L.; FRAGOSO, A. X.; SILVA, F. H. P.; ROCHA, P. G.; FONSECA, S. R.; ERRERA, F. I. V. Perfil da genética. Genética na escola, v. 7, n. 1, p. 11-23, 2012.

ARAUJO, A. A. C.; SANTOS, S. P. Olhares para o ensino em biologia: concepções de estudantes no ensino médio. In: ENDIPE, 17, 2014, Fortaleza. Anais... Fortaleza:

EdUECE, 2014, p. 03315-03319.

ARAÚJO, M. S.; FREITAS, W. L. S.; LIMA, S. M. S.; LIMA, M. M. O. A genética no contexto de sala de aula: dificuldades e desafios em uma escola pública de Floriano PI. Revista Ensino de Ciências e Matemática, v. 9, n. 1, p. 19-30, 2018.

BRÃO, A. F. S.; PEREIRA, A. M. T. B. Biotecnétika: possibilidades do jogo no ensino de genética. Electrónica de Enseñanza de Las Ciencias, v. 14, n. 1, p. 55-76, 2015.

CAMARGO, F; DAROS, T. A sala de aula inovadora: estratégias pedagógicas para fomentar o aprendizado ativo. Porto Alegre: Penso, 2018.

CAMPOS, L. M. L.; BORTOLOTO, T. M. A.; FELICIO, A. K. C. Produção de jogos didáticos para o ensino de ciências e biologia: uma proposta para favorecer a aprendizagem. Cadernos dos Núcleos de Ensino, São Paulo, p. 47-63, 2003.

CORDOVIL, R. V.; SOUZA, J. C. R.; FILHO, V. B. N. Lúdico: entre o conceito e a realidade educativa. In: FIPED, 8., 2016, Imperatriz. Anais... Imperatriz: Realize, 2016.

COSTA, E. A.; DUARTE, R. A. F.; GAMA, J. A. S.; A gameficação da botânica: uma estratégia para a cura da "cegueira botânica". Revista Insignare Scientia, v. 2, n. 4, p. 79-99, 2019.

COSTA, W. C.; PINHO, K. E. P. A importância e a contribuição do lúdico no processo educacional. Curitiba, 2008.

DE CAMPOS JÚNIOR. E. O.; PEREIRA, B. B.; LUIZ, D. P.; NETO, M. J. F.; BONETTI, A. M.; KERR, W. E. Sistema sanguíneo sem mistério: uma proposta alternativa. Genética na escola, v. 4, n. 1, p. 7-9, 2009.

DIAS, M. S.; CARLAN, F. A. Dificuldades de acadêmicos de ciências biológicas com conceitos de genética: um estudo mediado pelo aplicativo "biologados". Revistas tecnologias na Educação. Pelotas, v. 17, n. 8, p. 1-12, 2016.

FARDO, M. L. A gamificação aplicada em ambientes de aprendizagem: Novas Tecnologias na Educação. Cinted/UFRGS, v. 11, n. 1, p. 1-9, 2013.

FIALHO, N. N. Jogos no Ensino de Química e Biologia. Curitiba: IBPEX, 2007. 
FILHO, R. S.; ALLE, L. F.; LEME, D. M. Diagnosticando dificuldades no processo de ensino-aprendizagem de genética nas escolas e universidades. In: CONGRESSO DE NACIONAL DE EDUCAÇÃO, 5., 2018, Pernambuco. Anais... Pernambuco: Realize, 2018. p. 1-6.

FORTUNA, T. R. Sala de aula é lugar de brincar? In: XAVIER, M.L.F. e DALLA ZEN, M.I.H. Planejamento: análises menos convencionais. Porto Alegre: Mediação, 2000 (Cadernos de Educação Básica, 6) p. 147-164.

FREIRE, A. S. O jogo do genoma: um estudo sobre o ensino de Genética no Ensino Médio.2009.110 p. Tese (Doutorado em Ensino de Ciências e Saúde). Instituto Oswaldo Cruz, Rio de Janeiro, 2009.

GERHARDT, T. E.; SILVEIRA, D. T.; Métodos de Pesquisa. ed. Porto Alegre: UFRGS, 2009. $120 \mathrm{p}$.

GIL, A. C.; Como elaborar projetos de pesquisa. 4 ed. São Paulo: Atlas. S.A, 2002. $176 \mathrm{p}$.

GOMES, A. M.;OLIVEIRA, F. A.; SOUZA, S. A. S.; MOREIRA, P. A. Síndromes cromossômicas em uma nova perspectiva de aprendizagem. Genética na escola, v. 6, n. 1, p. 20-22, 2011.

GOLDBACH, T.; PEREIRA, W. A.; SILVA, B. A. F. S.; OKUDA, L. V. O.; SOUZA, N. R. Diversificando estratégias pedagógicas com jogos didáticos voltados para o ensino de biologia: ênfase em genética e temas correlatos. In: CONGRESO INTERNACIONAL SOBRE INVESTIGACIÓN EN DIDÁCTICA DE LAS CIENCIAS, 9. 2013. Girona. Anais... Girona: COMUNICACIÓN. 2013. p. 1566-1572.

GOLDBACH, T.; SARDINHA, R.; DYZARS. F.; FONSECA. M. Problemas e desafios para o ensino de genética e temas afins no ensino médio: dos levantamentos aos resultados de um grupo focal. In: ENCONTRO NACIONAL DE PESQUISA EM EDUCAÇÃO EM CIÊNCIAS, 7., 2009, Florianópolis. Anais... Florianópolis: ENPEC, 2009. p. 1-12.

GUIMARÃES, K. M. N.; OLIVEIRA, S. F.; AKIMOTO, A.; HIGARI, C.; BARBOSA, L. S.; ROCHA, D. M. S.; CORREIA, A. Combinar e recombinar com os dominós. Genética na escola, v. 3, n. 2, p. 1-7, 2008.

KISHIMOTO, T. M. O brinquedo na educação: considerações históricas. Ideias 7, FDE, n. 7, p. 39-45, 1990.

KRASILCHIK, M. Prática de ensino de biologia. 4. ed. Editoria Universidade de São Paulo: São Paulo, 2008. 194 p.

LEITE, L. M.; FERRO, A. R.; SAMPAIO, L. F.; CAPARROZ, R. Dominó gênico: interagindo para compreender a interação gênica. Genética na escola, v. 9, n. 1, p. 3037, 2014. 
LOVATO, F. L.; CHRISTO, T. M.; PAGLIARINI, D. S.; COSTA, F. R.; SANTOS, M. L. B. Na trilha dos genes: uma proposta de jogo didático para o ensino de Genética. Journal of Biochemistry Education, v. 16, n. 2, p. 6-30, 2018.

MARTINEZ, E. R. M.; FUJIHARA, R.T.; MARTINS, C. Show da Genética: um jogo interativo para o ensino de genética. Genética na Escola, v. 3, n. 2, p. 24-27, 2008.

MARTINS, I. C. P.; BRAGA, P. E. T. Jogo didático como estratégia para o Ensino de divisão celular. Ciências Biológicas. Sobral, v. 16, n. 02, p. 1-21, 2015.

MIRANDA, S. No fascínio do jogo, a alegria de aprender. Ciência Hoje, v. 28, n. 168, p. 64-66, 2001.

MORÁN, J. Mudando a educação com metodologias ativas. In: SOUZA, C. A.; MORALES, O. T. Convergências Midiáticas, Educação e Cidadania: aproximações jovens. Ponta Grossa: PROEX/UEPG, 2015. p. 15-35. (Coleção Mídias Contemporâneas).

NASCIMENTO, F. P. Classificação da Pesquisa. Natureza, método ou abordagem metodológica, objetivos e procedimentos. In: "Metodologia da Pesquisa Cientifica: teoria e prática - como elaborar TCC". 1. ed. Brasília: Thesaurus, 2016. p. 1-11.

PAES, M. F.; PARESQUE, R. Jogo da memória: onde está o gene?. Genética na escola, v. 4, n. 2, p. 26-29, 2009.

PAIM, F. G.; SENE, V. F.; MOTA, L. S. L. S. Memória genética. Genética na escola, v. 12, n. 1, p. 59-71, 2017.

PAIVA, L. R. S.; MARTINEZ, E. R. M.; GAMBARINI, G. H. R.; ALVES, J. C. P. Jogo banco genômico: trabalhando com genes e organismos transgênicos, uma prática para o ensino de genética. Genética na escola, v. 3, n. 2, p. 29-36, 2008.

RAU, M. C. T. D. A ludicidade na educação: uma atitude pedagógica. 2. ed. Curitiba: Ibipex, 2013. 249 p.

RAMALHO, M. A. P.; SILVA, F. B.; SILVA, G. S.; SOUZA, J. C. Ajudando a fixar os conceitos de genética. Genética na escola, v. 1, n. 2, p. 45-49, 2006.

SALOMÃO, H. A. S.; MARTINI, M.; JORDÃO, A. P. M. A importância do lúdico na Educação Infantil: enfocando a brincadeira e as situações de ensino não direcionado. Psicologia, 2007.

SANTOS, V. A.; LIMA, J. S. Jogos Leis de Mendel- Ensinando genética de forma lúdica. In: CONGRESSO BRASILEIRO DE INFORMÁTICA NA EDUCAÇÃO, 3. 2014, Garanhuns.; SIMPÓSIO BRASILEIRO DE INFORMÁTICA NA EDUCAÇÃO, 25., 2014, Garanhuns. Anais... Garanhuns: CBIE; SBIE, 2014. p. 687-681.

SNUSTAD, D. P.; SIMMONS, M. J. Fundamentos de genética. 6. ed. Rio de Janeiro:/ Guanabara Koogan, 2013. 
SANT'ANNA, I. C.; BRANCO, A. L. C.; PEREIRA, K. F.; CARVALHO, A. C. P.; TAVARES, M. G. Perfil da genética: uma maneira divertida de memorizar conteúdos. Genética na escola, 2011, v. 6, n. 2, p. 17-29, 2011.

SANTIAGO, S. A.; CARVALHO. H. F. Modelo tridimensional para o ensino da divisão celular. Genética na escola, v. 14, n. 2, p. 139-145, 2019.

SILVA, G. K. B.; SILVA, G. K. B. Gamificação: benefícios da utilização do jogo de tabuleiro no processo de ensino-aprendizagem das aulas de ciências. In: CONGRESSO NACIONAL DE EDUCAÇÃO DE TECNOLOGIAS, 2018, São Carlos.; ENCONTRO DE PESQUISADORES A DISTÂNCIA, 2018, São Carlos.; Anais... São Paulo: CIET; EnPED, 2018. p. 1 - 6.

SOUZA, E. S.; JUNIOR, F. H. N.; CAVALCANTE, C. A. M.; HOLANDA, D. A. S. A genética em sala de aula: uma análise das percepções e metodologias empregadas por professores das escolas públicas estaduais de Jaguaribe Ceará. Conex. Ci. e Tecnol, v. 10, n. 4, p. 16-24, 2016.

\section{SILVA, A. P. A importância dos jogos / brincadeiras para a aprendizagem dos} esportes nas aulas de educação física. São Luís, 2007. 57 p. Trabalho de Conclusão de Curso (Especialização em Esporte Escolar). Universidade Federal do Maranhão. 2007.

TEMP, D. S. Facilitando a aprendizagem de genética: uso de um modelo didático e análise dos recursos presentes em livros de biologia. 2011. 85 p. Dissertação (Mestrado em educação em ciências: química da vida e saúde). Universidade Federal de Santa Maria, Santa Maria, 2011.

TEMP, D. S.; SANTOS, M. L. B. O ensino de Genética: a visão de professores de Biologia. Revista Científica Schola, v. 2, n. 1, p. 83-95, 2018.

VALADARES, B. L. B.; RESENDE. R. O. Na trilha do sangue: o jogo dos grupos sanguíneos. Genética na escola, 2009, v. 4, n. 1, p. 10-16, 2009.

\section{ANEXOS}

\begin{tabular}{|c|}
\hline 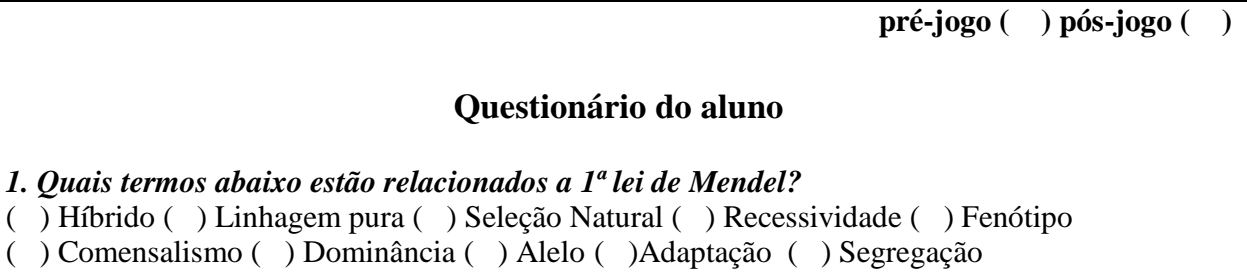 \\
\hline $\begin{array}{l}\text { 2. Qual (is) genótipo (s) corresponde (m) a um homozigoto recessivo? } \\
\begin{array}{llll}\text { ( ) } A a & \text { ( ) } b b & \text { ( ) } a a & \text { ( ) } A A\end{array}\end{array}$ \\
\hline $\begin{array}{l}\text { 3. As imagens } 1 \text { e } 2 \text { correspondem: } \\
1\end{array}$ \\
\hline
\end{tabular}




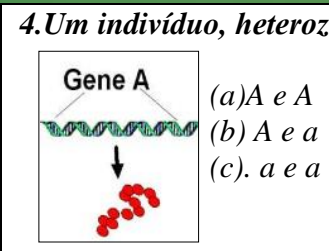

5. Qual o resultado do cruzamento entre ervilhas verdes (aa) e amarelas (Aa)?

(a) $A A, A a, A a, a a$

(b) $A A, A A, a a, a a$

(c) $A a, a a, A a, a a$

(d) $a a, a a, a a, A a$

(e) $A A, A A, A A, a a$

Quadro 1 - Questionário utilizado para avaliação do conhecimento dos alunos (pré-jogo) e como método avaliativo de contribuição do assunto (pós-jogo). Gabarito do questionário: 1. Híbrido, Linhagem pura, Dominância, Alelo, Recessividade, Fenótipo e Segregação; 2. bb e aa; 3. 1- Genótipo; 2- Fenótipo; 4. (b); 5. (c). Fonte: Autores (2020)

\title{
Questionário do professor
}

1. O jogo "Na Trilha com Mendel" trabalhado em sala ajudou na revisão do conteúdo?

2. Qual a sua percepção do jogo em sala, quanto ao tempo, participação e interação dos alunos?

3. Ao olhar a folha de resposta você conseguiria identificar as dificuldades de cada grupo, sim ou não? Se não, o que poderia ser feito para facilitar a visualização desse problema?

4. O(a) senhor(a) aplicaria o jogo 'Na Trilha com Mendel' em sua aula? Por que?

5. Pontos positivos do jogo:

6. Pontos negativos do jogo:

7. $\mathrm{O}$ (a) senhor(a) tem alguma sugestão para melhorar:

1. O jogo em si?

2. A aplicação do jogo?

\section{Quadro 2 - Questionário aplicado aos docentes das turmas.}

Fonte: Autores (2020)

\section{MANUAL DO JOGO "NA TRILHA COM MENDEL"}

\author{
$\checkmark \quad 1$ - Tabuleiro (50 casas) \\ $\checkmark \quad 1$ - Dado \\ $\checkmark \quad 4$ - Peões \\ $\checkmark \quad 1$ - Baralho com 45 cartas de perguntas (15 conceito, 15 abstrato e 15 complexo; de
} níveis (fácil, médio e difícil, nas cores verde, amarelo e vermelho, respectivamente)
$\checkmark \quad 1$ - Baralho com 12 cartas sorte ou azar
$\checkmark \quad$ Folhas de Respostas
$\checkmark \quad$ Gabarito de Respostas

\section{INSTRUÇÕES DO JOGO}

Pode ser jogado individualmente ou em equipes. Obs.: sugere-se dividir em equipes de no mínimo 2 e no máximo 4 pessoas.

Escolher um aluno mediador, que será responsável por anotar as informações na Folha de Respostas: número, categoria e nível da pergunta, bem como checar as respostas dos alunos consultando o Gabarito de Respostas. Esse aluno não fará parte de nenhuma das equipes que estão jogando. Obs.: A Folha de Respostas deverá ser entregue ao professor responsável da turma no final da atividade.

Para iniciar o jogo, as equipes deverão posicionar os seus peões na demarcação "início" no tabuleiro. Em seguida, cada equipe deverá jogar o dado, aquela que tirar o número maior será a primeira a jogar e assim sucessivamente. Obs.: em caso de empate, as equipes empatadas jogam o dado novamente. 
Ao cair na casa com o ponto de interrogação, a equipe deverá puxar uma carta do baralho de perguntas. A equipe avança ou retorna o número de casa indicado de acordo com as instruções contidas na carta sorteada. E devolve a carta para o fundo do baralho "perguntas".

A equipe que responder de forma incorreta ou não souber responder a pergunta da carta volta o número de casas indicado na carta sorteada.

A resposta, seja ela correta $(\mathrm{O})$ ou incorreta $(\mathrm{X})$, deverá ser indicada na Folha de Respostas. Uma folha pode ser compartilhada entre as equipes ou cada equipe preenche uma folha, a estratégia adotada fica a critério do professor responsável.

Ao cair na casa com o ponto de exclamação, a equipe retira uma carta do baralho de "sorte ou azar" e cumpre a instrução contida nela. E devolve a carta ao fundo do baralho "sorte ou azar".

Vence o jogo, a equipe que chegar primeiro ao final da trilha.

\section{CONSIDERAÇÕES SOBRE AS CARTAS}

$\checkmark \quad$ Perguntas fáceis: se acertar avança 1 casa, se errar volte 3 casas.

$\checkmark \quad$ Perguntas médias: se acertar avança 2 casas, se errar volte 2 casas.

$\checkmark \quad$ Perguntas difíceis: se acertar avança 3 casas, se errar volte 1 casa.

$\checkmark \quad$ Cartas com exclamação contém: 2 cartas "volte ao início", 2 cartas "jogue outra vez”, 2 cartas "fique uma rodada sem jogar", 2 cartas "permaneça na casa".

$\checkmark \quad$ Carta Desafio 1: Fique uma vez sem jogar

$\checkmark \quad$ Carta Desafio 2: Volte ao início

$\checkmark \quad$ Carta Desafio 3: Troque de lugar com uma equipe no tabuleiro

$\checkmark \quad$ Carta Desafio 4: Jogue novamente

$\checkmark \quad$ Carta Desafio 5: Permaneça onde está

$\checkmark \quad$ Carta Desafio 6: Volte três casas

$\checkmark \quad$ Carta Desafio 7: Volte duas casas

$\checkmark \quad$ Carta Desafio 8: Volte uma casa

$\checkmark \quad$ Carta Desafio 9: Escolha uma equipe para voltar três casas

$\checkmark \quad$ Carta Desafio 10: Escolha uma equipe para ficar uma rodada sem jogar

$\checkmark \quad$ Carta Desafio 11: Avance duas casas

$\checkmark \quad$ Carta Desafio 12: Avance uma casa

\section{Gabarito de respostas das perguntas do jogo}

\begin{tabular}{|l|l|}
\hline \multicolumn{2}{|c|}{ Gabarito de respostas } \\
\hline \multicolumn{2}{|c|}{ CATEGORIA: CONCEITo } \\
\hline Fácil & Questão 1: Verdadeiro \\
\hline Fácil & Questão 2: Verdadeiro \\
\hline Fácil & Questão 3: Letra b (alelo) \\
\hline Fácil & Questão 4: Letra c (gene) \\
\hline Fácil & Questão 5: Verdadeiro \\
\hline Médio & Questão 1: Verdadeiro \\
\hline Médio & Questão 2: Letra d (diploide) \\
\hline Médio & Questão 3: Falso \\
\hline Médio & Questão 4: Falso \\
\hline Médio & Questão 5: Letra c (cromossomo) \\
\hline Dificil & Questão 1: letra b (alelo dominante) \\
\hline Dificil & Questão 2: Verdadeiro \\
\hline Dificil & Questão 3: Letra a (hibrido) \\
\hline Difícil & Questão 4: Verdadeiro \\
\hline Dificil & Questão 5: Letra c (heterozigoto) \\
\hline
\end{tabular}

\begin{tabular}{|l|l|}
\hline \multicolumn{2}{|c|}{ Gabarito de respostas } \\
\hline \multicolumn{2}{|c|}{ CATEGORIA: ABSTRATO } \\
\hline Fácil & Questão 1: Falso \\
\hline Fácil & Questão 2: Verdadeiro \\
\hline Fácil & Questão 3: Falso \\
\hline Fácil & Questão 4: Falso \\
\hline Fácil & Questão 5: Verdadeiro \\
\hline Médio & Questão 1: Cromossomo \\
\hline Médio & Questão 2: Gene \\
\hline Médio & Questão 3: Molécula de DNA \\
\hline Médio & Questão 4: Pai e Mãe são heterozigotos (Aa) \\
\hline Médio & Questão 5: Pai Homozigoto recessivo(aa) e Mãe heterozigota(Aa) \\
\hline Difícil & Questão 1: Letra c (Homozigoto dominante) \\
\hline Dificil & Questão 2: Letra c (Heterozigoto) \\
\hline Difícil & Questão 3: Letra c (Homozigoto recessivo) \\
\hline Difíil & Questão 4: Letra b \\
\hline Difíil & Questão 5: Verdadeiro \\
\hline
\end{tabular}




\begin{tabular}{|l|l|}
\hline \multicolumn{2}{|c|}{ Gabarito de respostas } \\
\hline \multicolumn{1}{|c|}{ CATEGORIA: COMPLEXo } \\
\hline Fácil & Questão 1: Letra b (100\% ervilhas amarelas) \\
\hline Fácil & Questão 2: Letra e (2: AA para 2: Aa) \\
\hline Fácil & Questão 3: Letra c (50\% Aa e 50\% AA) \\
\hline Fácil & Questão 4: Letra e (75\% lisas e 25\% rugosas) \\
\hline Fácil & Questão 5: Letra b (2 amarelas para 2 verdes) \\
\hline Médio & Questão 1: Letra a (50\% flores roxas e 50\% flores brancas) \\
\hline Médio & Questão 2: Letra e (100\% indivíduos homozigotos dominantes) \\
\hline Médio & Questão 3: Letra d ( 25\% AA; 50\% Aa; 25\% aa) \\
\hline Médio & Questão 4: Letra b (100\% homozigoto recessivo) \\
\hline Médio & Questão 5: Letra c (100\% lisas) \\
\hline Difícil & $\begin{array}{l}\text { Questão 1: Letra d (F1 todas as plantas altas; F2 75\% plantas altas e } \\
\text { 25\% plantas baixas) }\end{array}$ \\
\hline Difícil & $\begin{array}{l}\text { Questão 2: Letra c (75\% indivíduos Rh+ (positivo) e 25\% Rh- } \\
\text { (negativo) }\end{array}$ \\
\hline Difícil & Questão 3: Letra e (2: AA para 2: Aa) \\
\hline Difícil & Questão 4: Letra b (pai Aa e mãe Aa) \\
\hline Difícil & Questão 5: Letra c (2: Aa para 2: aa) \\
\hline
\end{tabular}

\section{Cartas do Jogo}

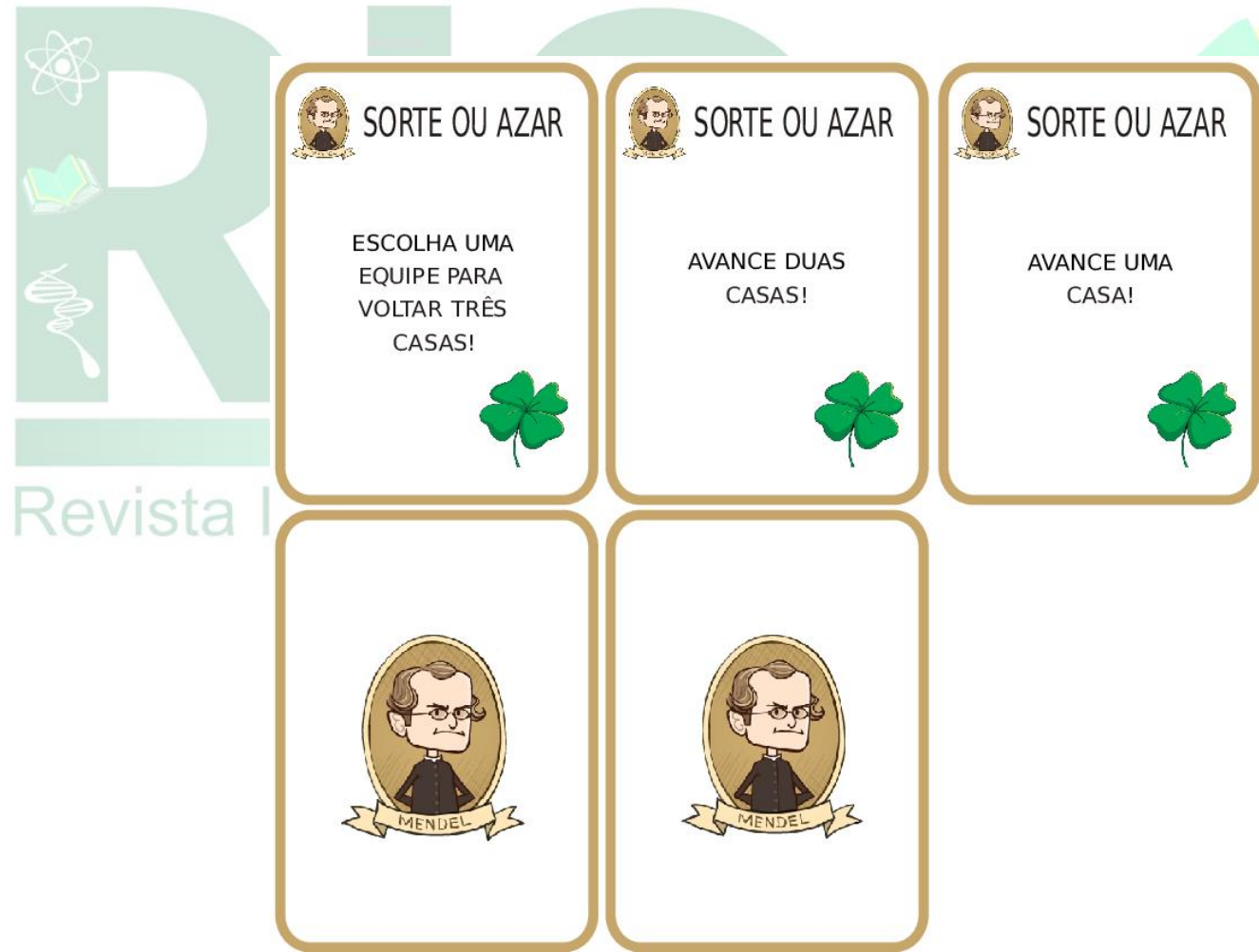




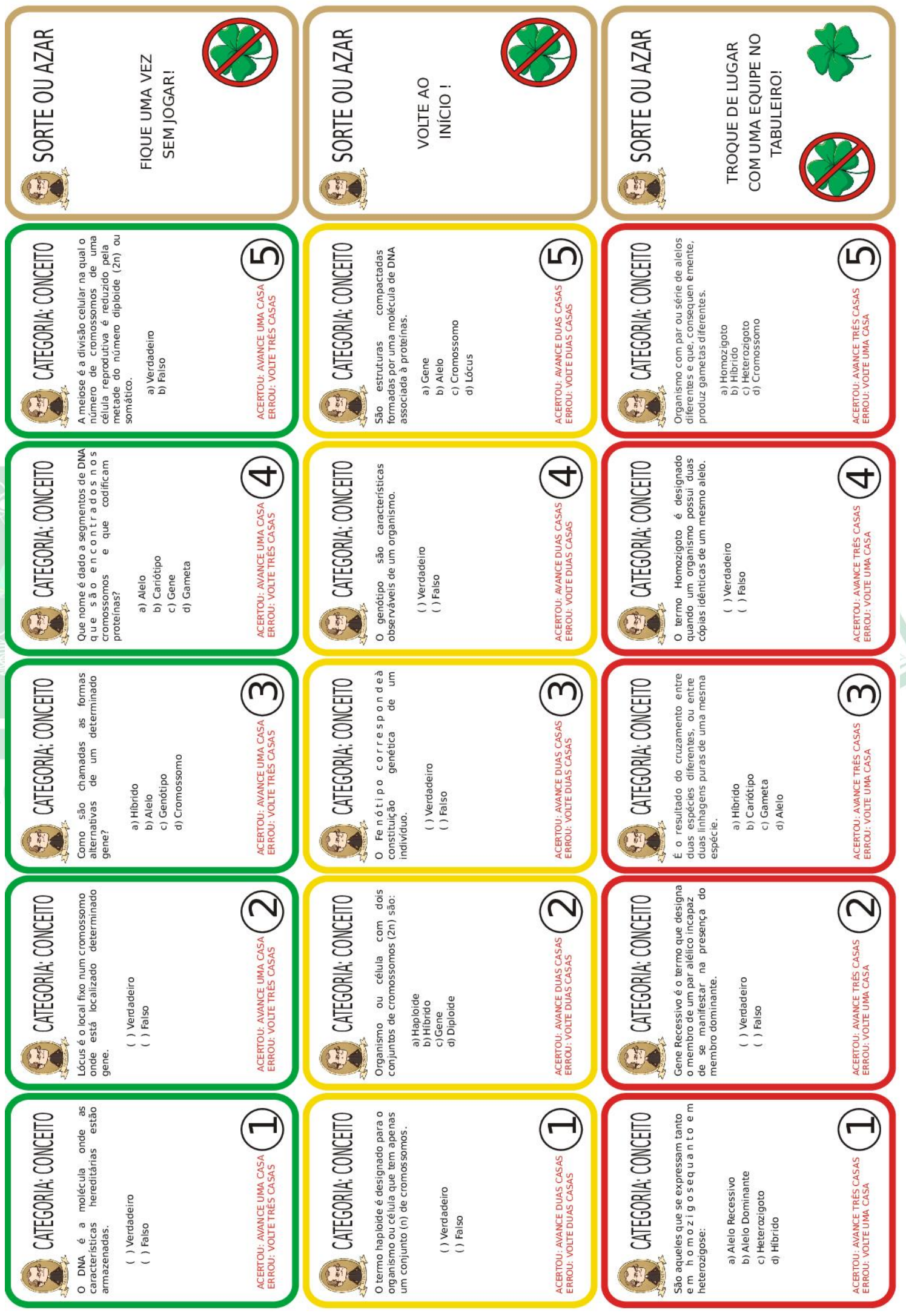




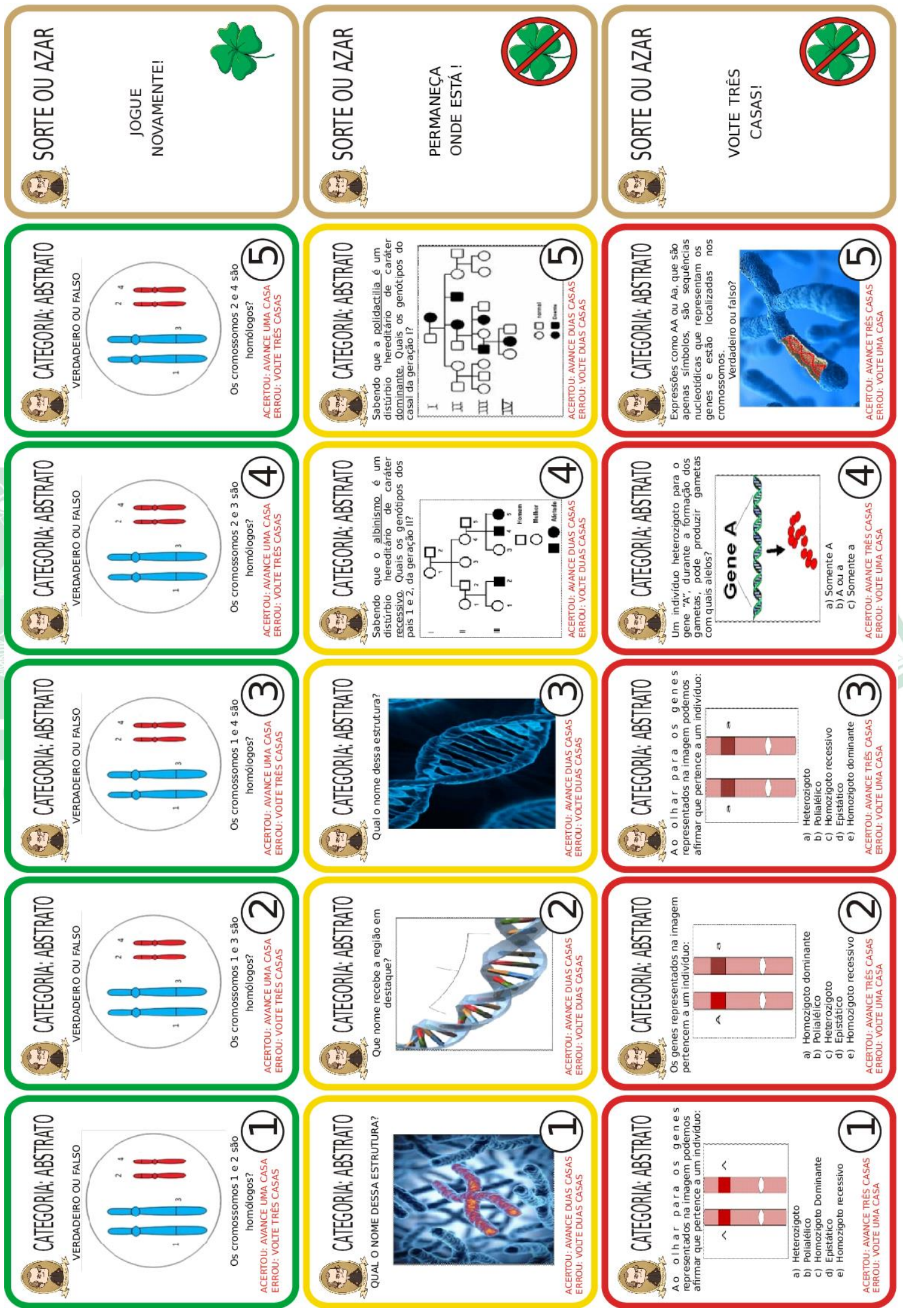




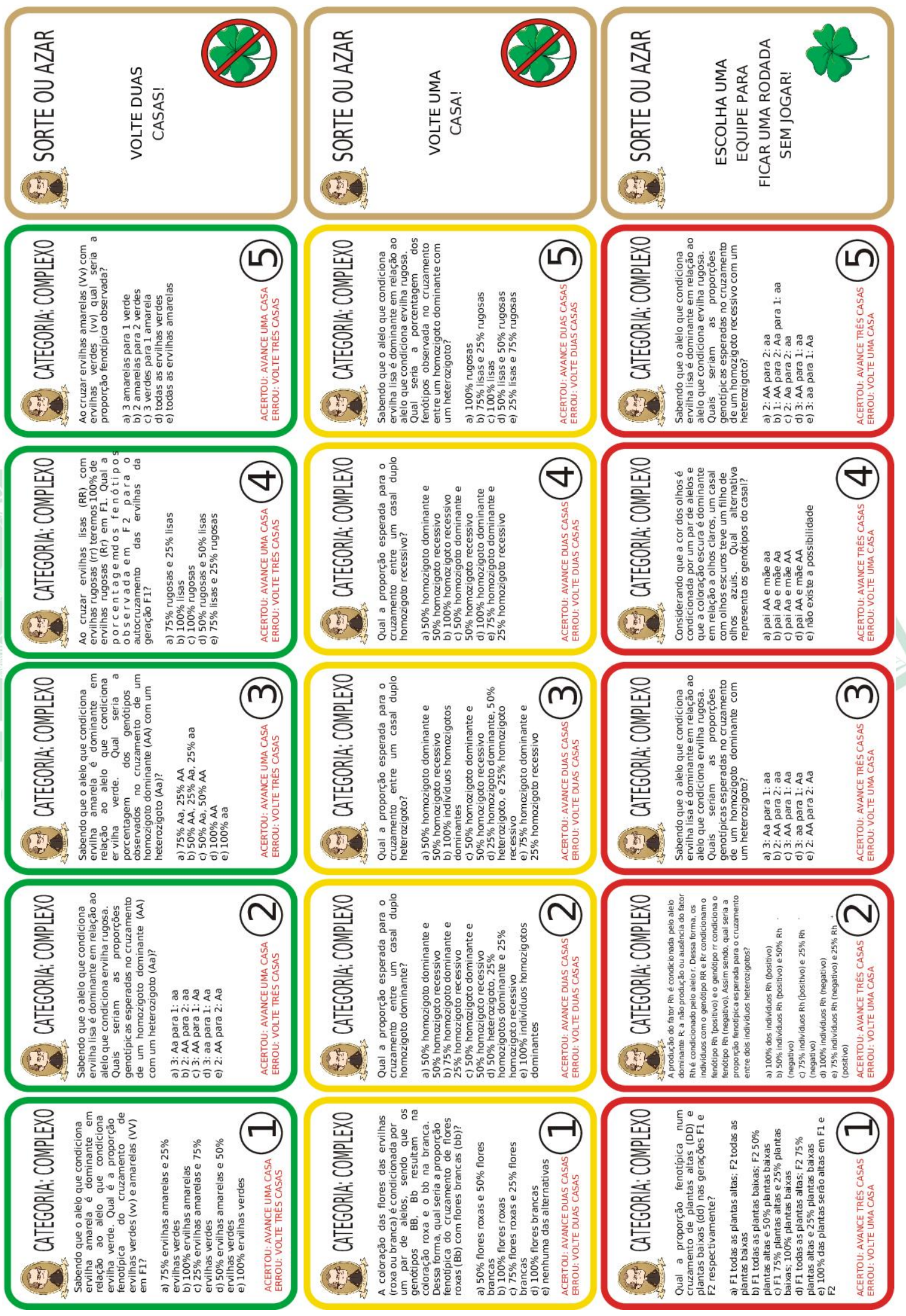

